\title{
CE versus HPLC for the dissolution test in a pharmaceutical formulation containing acetaminophen, phenylephrine and chlorpheniramine
}

\author{
A. Marín, C. Barbas* \\ Facultad de CC Experimentales y de la Salud, Universidad San Pablo-CEU, Urbanización Montepríncipe, \\ Boadilla del Monte, 28668 Madrid, Spain
}

Received 30 December 2003; received in revised form 5 March 2004; accepted 7 March 2004

Available online 18 May 2004

\begin{abstract}
A new polar reverse phase stationary phase has permitted our group to develop and validate an isocratic HPLC method for the simultaneous determination of acetaminophen, phenylephrine and chlorpheniramine in capsules as pharmaceutical formulation after their dissolution test. Final optimised chromatographic conditions employed a Supelco Discovery ${ }^{\circledR}$ HS PEG column (polyethylene glycol), $5 \mu \mathrm{m}, 15 \mathrm{~cm} \times 0.46 \mathrm{~cm}$. The mobile phase was $20 \mathrm{mM}$ phosphate buffer at $\mathrm{pH} 7.0 /$ acetonitrile $80: 20(\mathrm{v} / \mathrm{v})$ at a flow rate of $1 \mathrm{ml} / \mathrm{min}$. UV detection was performed at $210 \mathrm{~nm}$ for phenylephrine and chlorpheniramine and at $305 \mathrm{~nm}$ for acetaminophen. On the other hand, to evaluate the capability of CE to work in a routine analytical method fulfilling the pharmaceutical requirements and to study the behaviour of the technique with these compounds, we developed a CE method with the same objective. Normal and reverted polarity, the $\mathrm{pH}$ and concentration of the buffer, and the presence and concentration of surfactants were assayed. Forty millimolar phosphate buffer at pH 6.20 with $0.5 \mathrm{mM}$ SDS at $30 \mathrm{kV}$ in an uncoated silica capillary provided a runtime of $4.5 \mathrm{~min}$ to separate the three analytes and the excipients. Moreover, parameters affecting precision in $\mathrm{CE}$, such as the injection of buffer after the sample to refill the capillary were also tested. After development, the validation was performed in parallel for HPLC and CE with the same standards and samples to avoid differences due to the manipulation. The validation parameters of both techniques were adequate for the intended purpose.
\end{abstract}

(C) 2004 Elsevier B.V. All rights reserved.

Keywords: Common cold; Capsules; Polyethylene glycol; Validation

\footnotetext{
* Corresponding author. Tel.: +34-91-372-4711; fax: +34-91-351-0475.

E-mail address: cbarbas@ceu.es (C. Barbas).
}

\section{Introduction}

Pharmaceutical formulations against the common cold use to contain compounds in very different proportion and with very different polarities such as acetaminophen, phenylephrine and chlorpheniramine. Due to these characteristics and because of diverse 
properties inherent to their formulation and desired action, these preparations offer an analytical problem. Even more, when analysing the dissolution test samples where the concentrations of some of the actives can be very low.

Dissolution test is considered to be one of the most important quality control tests performed on pharmaceutical dosage forms because it is a qualitative tool which can provide valuable information about biological availability of a drug as well as batch-to-batch reproducibility [1-4]. The analysis of dissolution test samples is usually carried out using UV spectrophotometry or HPLC for complex combinations of products. In a previous work [5] we carried out a detailed review of the analytical methods published for measuring some of these substances, alone or in different combinations. Three methods in the literature report the simultaneous quantification of acetaminophen, chlorpheniramine and phenylephrine, but none of them applied for dissolution test. The method of Senyuva and Ozden [6] permits the rapid determination of the three actives in combined pharmaceutical dosage forms using a Bondapak CN column, nevertheless acetaminophen is not separated from the solvent front, with the corresponding quantification problems, and there is no space for the impurities. The method of Kanumula et al. [7] that uses wavelength programming and pseudoephedrine hydrochloride as internal standard and the method developed by Krieger [8] for the separation of acetaminophen in analgesic preparations containing chlorpheniramine maleate, phenylephrine hydrochloride, and other active components by HPLC. Other reports describe the simultaneous separation by HPLC of acetaminophen, chlorpheniramine and phenylpropanolamine, which is a compound that appears in some formulations instead of phenylephrine [9-11]. In our last work we developed and validated an isocratic HPLC method for the simultaneous determination of the three actives in capsules as pharmaceutical formulations, including the separation of impurities and excipients [12]. The chromatographic method was an interesting advance because it was isocratic and the run time was less than $12 \mathrm{~min}$. It was developed by using new polar reverse phase stationary phases in HPLC, such as polyethyleneglycol, that provide with specific selectivity.

On the other hand, in spite of the quality control analysis of pharmaceuticals is currently performed predominantly using HPLC, many pharmaceutical analysis laboratories have an increasing presence of $\mathrm{CE}$ instrumentation, so CE offers a real and attractive alternative to HPLC. CE in many instances can have different advantages over HPLC in terms of rapid method development, reduced operating costs and increased simplicity [13]. In many laboratories reliable and reproducible results are routinely obtained in CE if the methods are correctly optimised, described, validated and applied by operators using good working practices. At the moment, only mixtures of acetaminophen and chlorpheniramine alone or in combination with other cold medicines such as phenylpropanolamine has been separated by MECC [14-18] and by EKC employing bile salts [19]. The aim of the present work was the optimisation and validation of chromatographic and electrophoretic methods for the measurement of acetaminophen, phenylephrine and chlorpheniramine in capsules as pharmaceutical formulation after their dissolution test.

\section{Experimental}

\subsection{Chemicals}

Standards of acetaminophen, phenylephrine and chlorpheniramine as well as capsules and excipients of the speciality were kindly provided by CINFA, S.A. (Pamplona, Spain). Phosphoric acid $85 \%$ and SDS were from Merck (Darmstadt, Germany). CTAB was from Fluka (Madrid, Spain). $\mathrm{NaOH}$ and the other organic solvents were HPLC grade from Scharlab (Barcelona, Spain).

\subsection{Chromatographic system}

HPLC system was an Agilent technologies 1100 series (Las Rozas, Madrid, España) provided with an automatic injector, a diode-array detector and a column oven. The chromatographic analysis were performed on a $5 \mu \mathrm{m}$ particle, Discovery HS PEG (polyethylene glycol) column (Supelco, Alcobendas, Madrid, Spain), $15 \mathrm{~cm} \times 0.46 \mathrm{~cm}$, kept at $35^{\circ} \mathrm{C}$.

Final chromatographic conditions were an isocratic elution with phosphate buffer $20 \mathrm{mM}$ at $\mathrm{pH}$ $=7.0 /$ acetonitrile, 80:20 (v/v). The phosphate buffer was prepared from $\mathrm{H}_{3} \mathrm{PO}_{4}$ by adding $\mathrm{NaOH}$ to reach 
the $\mathrm{pH}$ 7.0. The flow rate was $1 \mathrm{ml} / \mathrm{min}$ and the injection volume was $50 \mu$ l. UV detection was performed at $210 \mathrm{~nm}$ for phenylephrine and chlorpheniramine, because at this wavelength the sensitivity was higher than in other more characteristic wavelengths and it was necessary for the detection of these minor compounds. For acetaminophen $305 \mathrm{~nm}$ was employed. At this wavelength the absorbance for this compound is very low and the signal is not saturated with the large amount of acetaminophen present in the sample to be able to detect the minor compounds simultaneously.

\subsection{Capillary electrophoresis system}

Capillary electrophoresis was a P/ACE 5500 (Beckman) with UV detection at $200 \mathrm{~nm}$. The separation was carried out with an uncoated fused-silica capillary $(57 \mathrm{~cm} \times 50 \mu \mathrm{m}$ i.d.). During the development of the analytical method both polarity modes were tested. Final conditions were normal polarity, injection at the positive end (anode) and detection at the negative end (cathode) with $30 \mathrm{kV}$ of applied potential. Separation buffer was prepared with $40 \mathrm{mM} \mathrm{H}_{3} \mathrm{PO}_{4}$ made up $\mathrm{pH}$ 6.20 with $\mathrm{NaOH}$, and with $0.5 \mathrm{mM}$ SDS added. The injection was by pressure ( $3.3 \mathrm{bar}$ ) first $5 \mathrm{~s}$ for sample and then $5 \mathrm{~s}$ for buffer. Temperature was maintained at $25^{\circ} \mathrm{C}$. The capillary was flushed between runs with the BGE for $1 \mathrm{~min}$. Fresh new vial buffers were replaced after each six samples.

\subsection{Dissolution test system}

The dissolution rates of acetaminophen, phenylephrine and chlorpheniramine from commercial capsules were measured using an Erweka dissolution apparatus with six glasses (Gomensoro, Madrid, Spain).

\subsection{Preparation of standard solutions}

A stock solution of phenylephrine was prepared with $434.0 \mathrm{mg}$ of phenylephrine hydrochloride exactly weighed and dissolved with methanol/water 1:1 (v/v) in a $25 \mathrm{ml}$ volumetric flask. For chlorpheniramine maleate stock solution, $173.6 \mathrm{mg}$ were made up $25 \mathrm{ml}$ with methanol/water 1:1 (v/v). For the reference stock standard, $434.0 \mathrm{mg}$ of acetaminophen were weighed in a $25 \mathrm{ml}$ volumetric flask and $0.5 \mathrm{ml}$ of phenylephrine and chlorpheniramine solutions were added and the volume was made up with methanol/water 1:1 (v/v).
The working standard (corresponding to $100 \%$ of each compound dissolved) was prepared with $0.8 \mathrm{ml}$ of the stock standard diluted to $25 \mathrm{ml}$ with purified water.

\subsection{Dissolution and analysis procedure}

One capsule $(\sim 610 \mathrm{mg})$ was added in each one of the six glasses, using $900 \mathrm{ml}$ of water at $37 \pm 0.5^{\circ} \mathrm{C}$ as dissolution medium. The equipment was operated with baskets at $100 \mathrm{rpm}$. Samples aliquots of $10 \mathrm{ml}$ were taken at $45 \mathrm{~min}$ and filtered through $0.45 \mu \mathrm{m}$ nylon filters to the HPLC or CE vials.

\subsection{Optimization of HPLC method}

For method development in HPLC, the most important parameters that modify the selectivity in the chromatographic separation such as the $\mathrm{pH}$ of the mobile phase, the concentration of the buffer and the organic percentage were studied in order to find a new rapid and precise method to quantify the three actives in capsules after the dissolution test. Results are shown below.

\subsection{Optimization of CE method}

Selectivity in CZE can be controlled by background electrolyte concentration, $\mathrm{pH}$, organic modifiers, presence of surfactants and polarity. All these parameters were varied and results are summarised below. Moreover, parameters affecting precision in $\mathrm{CE}$, such as the injection of buffer after the sample to refill the capillary were also tested.

\subsection{Validation}

The validation was performed in parallel for HPLC and $\mathrm{CE}$ with the same standards and samples to avoid differences due to the manipulation.

Linearity for standards was tested assaying by triplicate seven levels of concentrations ranging from 6.25 to $125 \%$ and corresponding to 34.722 to $694.44 \mathrm{mg} / \mathrm{l}$ for acetaminophen; 0.694 to $13.89 \mathrm{mg} / \mathrm{l}$ for phenylephrine and 0.278 to $5.56 \mathrm{mg} / \mathrm{l}$ for chlorpheniramine. These solutions were prepared with 0.050 to $1.000 \mathrm{ml}$ of the stock standard in $25 \mathrm{ml}$ volumetric flask with purified water. Linearity for samples was tested in the same way, but including the proportional amount of excipients of the capsules. 
The accuracy of the method was tested by the percent recoveries and R.S.D. and it was estimated comparing the values obtained in samples linearity, with those in standards linearity.

Instrumental precision was tested by consecutively running six injections each day of the same standard mixture, corresponding to the $100 \%$ of the calibration curve.

Method precision was evaluated by processing separately six samples each day of a homogeneous mixture of powder from the capsules plus a clean empty capsule. Samples were independently prepared according to the dissolution procedure with the corresponding standards for calibration.

Method and instrumental intermediate precision data were obtained by repeating intra-assay experiment on a different day.

\section{Results and discussion}

\subsection{HPLC method optimization}

Starting conditions were those of our previous work [12], briefly a Supelco Discovery ${ }^{\circledR}$ HS PEG column (polyethyleneglycol), that achieved an increased retention of polar species, which are retained away from the solvent front, and decreased retention of non-polar compounds, which reduces the total analysis time. However, as this method was developed for impurity profiling, it was optimised to obtain a shorter run time in the dissolution assay and to solve the problem due to the polarity of the sample solvent. Small variations on the percentage of acetonitrile in the mobile phase showed little influence in the retention times of more polar compounds, while increasing retention time for chlorpheniramine. 80:20 phosphate buffer/acetonitrile $(\mathrm{v} / \mathrm{v})$ was chosen as the best option for the dissolution test. Buffer concentration showed little influence, but $20 \mathrm{mM}$ phosphate buffer seemed to give the best results.

The dissolution medium of the standards resulted critical as much for their chromatographic profile as for the quantification, mainly for phenylephrine, the more polar of them. As it is known less polar solvents facilitate standards dissolution but provide wide and non-Gaussian peaks when injected in a more polar mobile phase. Therefore, standards were initially solved in methanol at a high concentration and a second dilution in water with only $2 \%$ methanol in the flask gave to obtain the same profile than the samples dissolved in pure water for the test. Final conditions were summarised in the paragraph of chromatographic conditions and the corresponding chromatograms are shown in Fig. 1. These conditions allowed the maximum degree of optimization in HPLC with the shorter run time, because higher proportion of organic modifier produced overlapping of phenylephrine peak with the shift in the baseline due to the dissolution media.

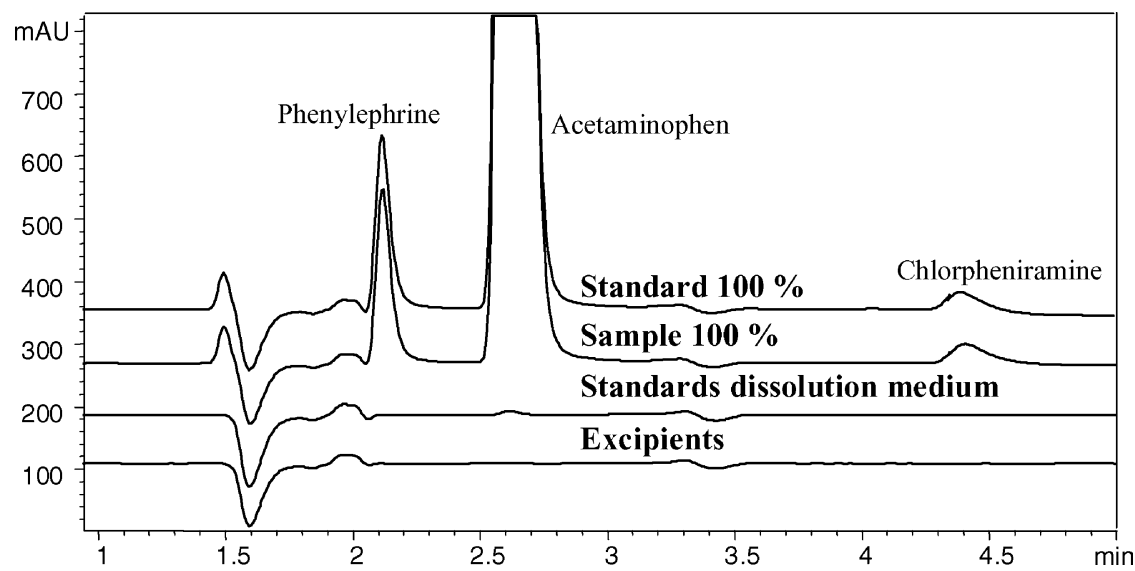

Fig. 1. Chromatogram of a standard, a synthetic sample, the standard dissolution medium and excipients. Column: Discovery HS PEG (polyethyleneglycol) $5 \mu \mathrm{m}, 4.6 \mathrm{~mm} \times 150 \mathrm{~mm}$ (Supelco). Mobile phase: $80 \% 20 \mathrm{mM}$ phosphate buffer $/ 20 \%$ acetonitrile. Flow: $1 \mathrm{ml} / \mathrm{min}$. $\lambda$ : $210 \mathrm{~nm}$. Temperature: $35^{\circ} \mathrm{C}$. 
Reverted polarity

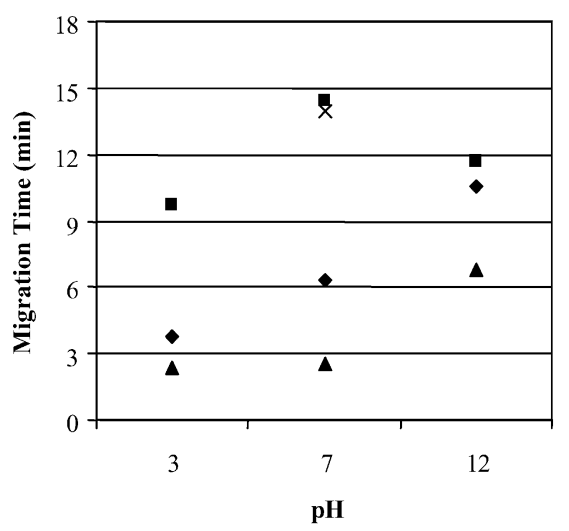

- Acetaminophen - Phenylephrine
Normal polarity

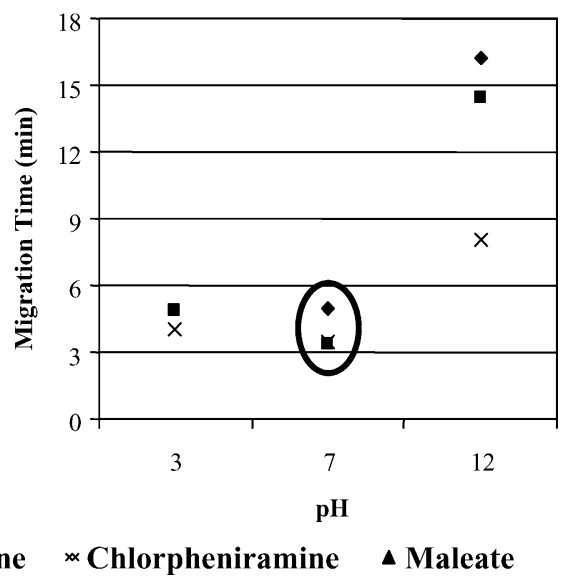

Fig. 2. Comparison of the migration times of standards in reverted and normal polarity. Uncoated silica capillary $(57 \mathrm{~cm} \times 75 \mu \mathrm{m}) .40 \mathrm{mM}$ Phosphate buffer at different $\mathrm{pH}$ values with $0.05 \mathrm{mM}$ SDS added for normal polarity or $0.5 \mathrm{mM}$ CTAB for reverted polarity. Applied current $100 \mu \mathrm{A}(30 \mathrm{kV})$. Detection at $200 \mathrm{~nm}$.

\subsection{CE method development}

Next step was method development in CE. Fortunately, once prepared the different buffers, assays are conducted by the equipment unattended. At first instance, polarity was selected by running the three stan- dards at different $\mathrm{pHs}$, and adding $0.05 \mathrm{mM}$ SDS for normal polarity and $0.5 \mathrm{mM} \mathrm{CTAB}$ for reverted polarity, applying a constant current of $100 \mu \mathrm{A}(\sim 30 \mathrm{kV})$. Results have been summarised in Fig. 2 and as can be seen, at pH 7 with normal polarity, injection at the positive end (the anode) and detection at the negative

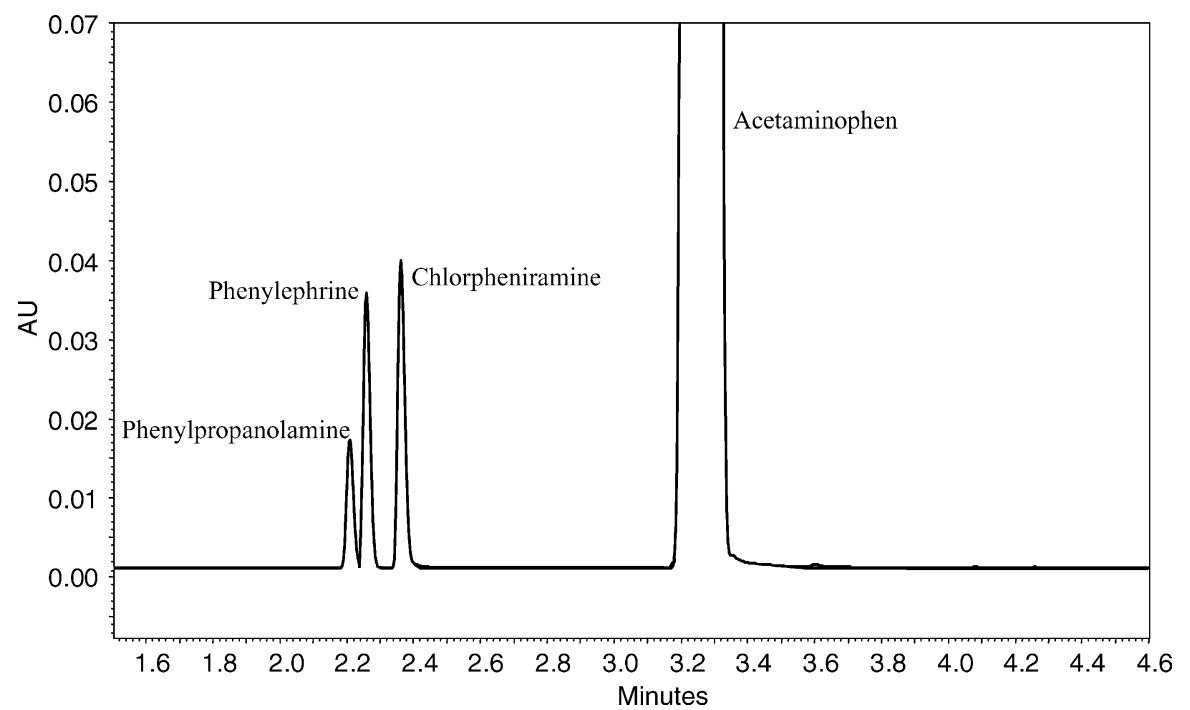

Fig. 3. Electropherogram of a mixture of phenylpropanolamine $(0.078 \mathrm{mg} / \mathrm{ml})$ phenylephrine $(0.043 \mathrm{mg} / \mathrm{ml}), \mathrm{chlorpheniramine}(0.037 \mathrm{mg} / \mathrm{ml})$ and acetaminophen $(1 \mathrm{mg} / \mathrm{ml})$. CE conditions: uncoated silica capillary $(57 \mathrm{~cm} \times 75 \mu \mathrm{m}$ i.d.). Normal polarity. Background electrolyte: $40 \mathrm{mM}$ phosphate buffer at $\mathrm{pH} 6.20$ with $0.05 \mathrm{mM}$ of SDS. Applied current: $100 \mu \mathrm{A}$. UV detection: $200 \mathrm{~nm}$. Temperature: $25^{\circ} \mathrm{C}$. 


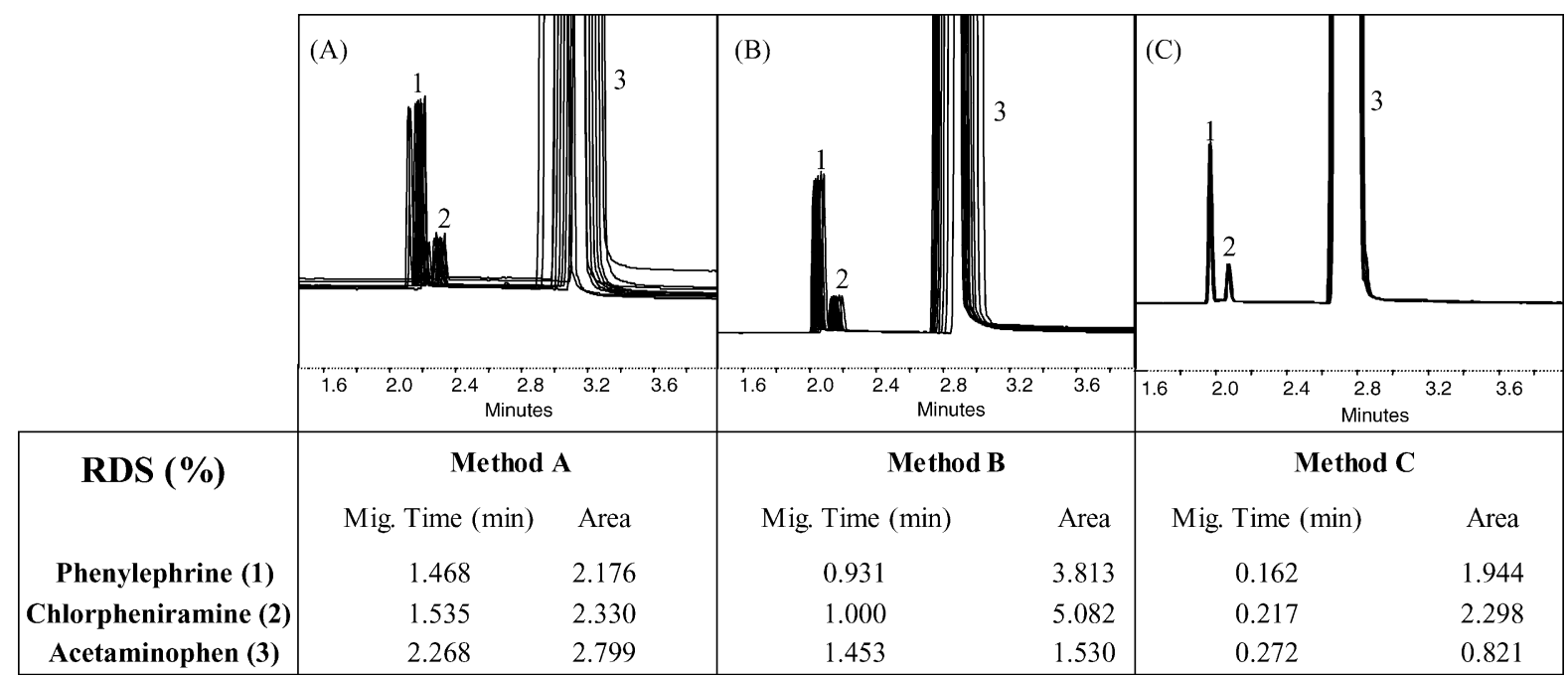

Fig. 4. Effect of capillary treatment between runs in the repeatability of the method. Ten electropherograms of a standard mix overlaid and their R.D.S.s (\%) for migration times and areas in a capillary conditioning with A: $\mathrm{NaOH}, \mathrm{H}_{2} \mathrm{O}$, running buffer and $5 \mathrm{~s}$ of injecting sample. B: running buffer and $5 \mathrm{~s}$ of injecting sample. C: running buffer and $5 \mathrm{~s}$ of injecting buffer after $5 \mathrm{~s}$ of sample. CE conditions: uncoated silica capillary $(57 \mathrm{~cm} \times 75 \mu \mathrm{m}$ i.d.). Normal polarity. Background electrolyte: $40 \mathrm{mM}$ phosphate buffer at $\mathrm{pH} 6.20$ with $0.5 \mathrm{mM}$ of SDS. Applied current: $100 \mu \mathrm{A}$. UV detection: $200 \mathrm{~nm}$. Temperature: $25^{\circ} \mathrm{C}$.

end (the cathode), the three actives appeared with the shorter retention time and those were the conditions selected for a further optimisation. When buffers with pH ranging from 6.00 to 8.00 with 0.2 increments were tested, $\mathrm{pH} 6.2$ gave the best resolution with minimum analysis time, including the separation of phenylpropanolamine, which can be included in some formulations instead of phenylephrine as shown Fig. 3. The

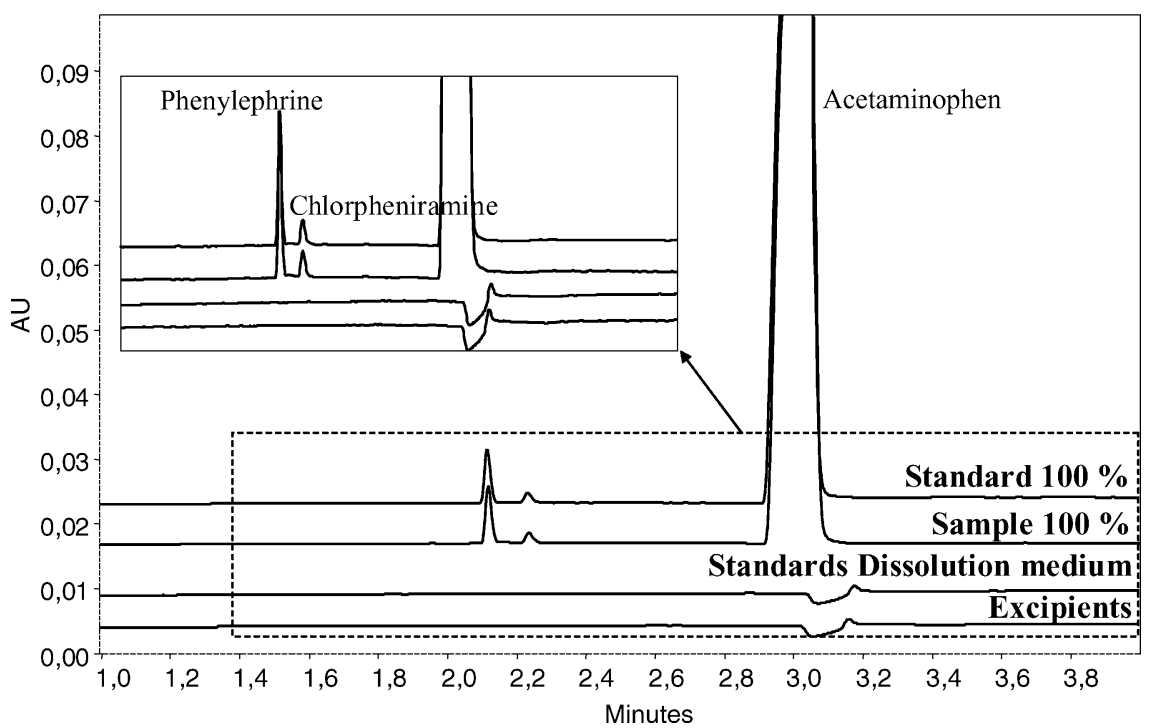

Fig. 5. Electropherogram of a standard, a synthetic sample, the standard dissolution medium and excipients. CE conditions: uncoated silica capillary $(57 \mathrm{~cm} \times 75 \mu \mathrm{m}$ i.d.). Normal polarity. Background electrolyte: $40 \mathrm{mM}$ phosphate buffer at pH 6.20 with $0.5 \mathrm{mM}$ of SDS. Applied voltage: $30 \mathrm{kV}$. Injection time: $5 \mathrm{~s}$ sample $+5 \mathrm{~s}$ of running buffer. UV detection: $200 \mathrm{~nm}$. Temperature: $25^{\circ} \mathrm{C}$. 
effect of buffer concentration in the background electrolyte was also tested and, as expected, lower concentrations provided lower migration times. Therefore, $40 \mathrm{mM}$ phosphate was chosen because it gave baseline resolution and shorter running time. The concentration of surfactant was also tested at concentrations under the critical micellar concentration. $0.5 \mathrm{mM}$ SDS slightly improved acetaminophen peak shape providing higher efficiency and not affecting the other two compounds and it was included in the buffer. Finally, it was observed that the presence of a small percentage of organic modifier in the BGE, methanol or acetonitrile, deteriorated the aspect of the peaks and they were avoided.

One of the weak points in many CE methods is the description of capillary treatment between runs and it greatly affects reproducibility. In the Fig. 4A it can be observed the overlay of ten injections corresponding to a capillary conditioned with sodium hydroxide, water and running buffer. In Fig. 4B the capillary was conditioned only with the running buffer. Meanwhile, in Fig. 4C the effect of injecting a buffer plug after the sample, in a capillary conditioned with running buffer, can be appreciated. This treating was previously recommended by Altria and Fabre [20]. In all cases the calculated R.S.D. for migration times and areas are shown. As can be observed, they were lower in the last case. Therefore, BGE injection after the sample is highly recommended to obtain more precise methods.

Finally, $40 \mathrm{mM}$ phosphate buffer at pH 6.20 with $0.5 \mathrm{mM}$ SDS at $30 \mathrm{kV}$ in an uncoated silica capillary provided a runtime of $3.5 \mathrm{~min}$ to separate the three analytes and the excipients as it is shown in Fig. 5.

Table 1

Main validation parameters of the HPLC and CE methods for linearity

\begin{tabular}{|c|c|c|}
\hline Linearity and range & HPLC & $\mathrm{CE}$ \\
\hline \multicolumn{3}{|l|}{ Acetaminophen } \\
\hline $\begin{array}{l}\text { Linearity range (\%) } \\
\quad\left(\mathrm{mg} \mathrm{ml}^{-1}\right)\end{array}$ & $\begin{array}{c}25-125 \\
0.13889-0.69444\end{array}$ & $\begin{array}{c}12.5-125 \\
0.06944-0.69444\end{array}$ \\
\hline $\begin{array}{l}\text { Standards linearity }(a \pm \mathrm{CL}) \\
\quad(\mathrm{b} \pm \mathrm{CL}) \\
\quad(r)\end{array}$ & $\begin{array}{c}89 \pm 37 \\
4455 \pm 81 \\
0.9995\end{array}$ & $\begin{array}{c}11369 \pm 4078 \\
1819735 \pm 9654 \\
0.99995\end{array}$ \\
\hline $\begin{array}{l}\text { Sample linearity }(a \pm \mathrm{CL}) \\
\quad(b \pm \mathrm{CL}) \\
\quad(r)\end{array}$ & $\begin{array}{c}93 \pm 27 \\
4429 \pm 58 \\
0.9998\end{array}$ & $\begin{array}{c}12256 \pm 7647 \\
1809130 \pm 18103 \\
0.9998\end{array}$ \\
\hline \multicolumn{3}{|l|}{ Phenylephrine } \\
\hline $\begin{array}{l}\text { Linearity range }(\%) \\
\quad\left(\mathrm{mg} \mathrm{ml}^{-1}\right)\end{array}$ & $\begin{array}{c}25-125 \\
0.00278-0.01389\end{array}$ & $\begin{array}{c}6.25-125 \\
0.00069-0.01389\end{array}$ \\
\hline $\begin{array}{l}\text { Standards linearity }(a \pm \mathrm{CL}) \\
\quad(b \pm \mathrm{CL}) \\
\quad(r)\end{array}$ & $\begin{array}{c}111 \pm 37 \\
114783 \pm 4043 \\
0.998\end{array}$ & $\begin{array}{c}88 \pm 124 \\
1161261 \pm 15925 \\
0.9996\end{array}$ \\
\hline $\begin{array}{l}\text { Sample linearity }(a \pm \mathrm{CL}) \\
\quad(b \pm \mathrm{CL}) \\
\quad(r)\end{array}$ & $\begin{array}{c}119 \pm 23 \\
112288 \pm 2477 \\
0.9993\end{array}$ & $\begin{array}{c}65 \pm 153 \\
1140127 \pm 19678 \\
0.9993\end{array}$ \\
\hline \multicolumn{3}{|l|}{ Chlorpheniramine } \\
\hline $\begin{array}{l}\text { Linearity range (\%) } \\
\qquad\left(\mathrm{mg} \mathrm{ml}^{-1}\right)\end{array}$ & $\begin{array}{c}25-125 \\
0.00111-0.00556\end{array}$ & $\begin{array}{c}25-125 \\
0.00111-0.00556\end{array}$ \\
\hline $\begin{array}{l}\text { Standards linearity }(a \pm \mathrm{CL}) \\
\quad(b \pm \mathrm{CL}) \\
\quad(r)\end{array}$ & $\begin{array}{c}-16 \pm 6 \\
113677 \pm 1648 \\
0.9997\end{array}$ & $\begin{array}{c}-67 \pm 135 \\
667228 \pm 36489 \\
0.996\end{array}$ \\
\hline $\begin{array}{l}\text { Sample linearity }(a \pm \mathrm{CL}) \\
\quad(b \pm \mathrm{CL}) \\
\quad(r)\end{array}$ & $\begin{array}{c}-15 \pm 22 \\
108246 \pm 5850 \\
0.996\end{array}$ & $\begin{array}{c}-39 \pm 103 \\
600183 \pm 27732 \\
0.997\end{array}$ \\
\hline
\end{tabular}


Table 2

Accuracy and recovery of the HPLC and CE methods

\begin{tabular}{lcc}
\hline Accuracy & HPLC & CE \\
\hline Acetaminophen & & \\
Standards & $100 \pm 1$ & $99.8 \pm 0.9$ \\
R.S.D. (\%) & 1.738 & 1.754 \\
Samples & $100 \pm 1$ & $100 \pm 1$ \\
R.S.D. (\%) & 1.546 & 2.256 \\
Phenylephrine & & \\
Standards & $99 \pm 2$ & $100 \pm 1$ \\
R.S.D. (\%) & 3.788 & 3.071 \\
Samples & $100 \pm 1$ & $101 \pm 2$ \\
R.S.D. (\%) & 2.627 & 3.364 \\
Chlorpheniramine & & \\
Standards & $100 \pm 1$ & $101 \pm 3$ \\
R.S.D. (\%) & 2.126 & 5.786 \\
Samples & $101 \pm 2$ & $100 \pm 2$ \\
R.S.D. (\%) & 3.945 & 3.778 \\
\hline
\end{tabular}

\subsection{Validation}

After development, the validation was performed in parallel for HPLC and CE with the same standards and samples to avoid differences due to the manipulation. It is important to point out that validation was performed to check the performance of the analytical methods and not the dissolution test. Selectivity was confirmed by separated injection of excipients and solvents from standards.
Main validation parameters of the method for linearity are shown in Table 1.

As can be observed limits of quantification, the lower value in the range, were lower for $\mathrm{CE}$ than for HPLC in spite of being CE a technique considered less sensible due to the injection of very small volumes. It was related to the higher precision in the areas of the corresponding peaks in $\mathrm{CE}$ at lower levels of concentration than in HPLC and it could be due to the higher peak efficiency in CE that provides better signal/noise values. Nevertheless, both techniques provide a linear range wide enough for the three actives and no bias was observed.

Accuracy was evaluated with recoveries obtained in the analysis of synthetic samples prepared in the laboratory through the linear range at seven levels of concentrations, from 6.25 to $125 \%$ and compared with the corresponding standards. The mean recoveries included the $100 \%$ for both techniques as it is shown in Table 2. The range was spanned up to $6.25 \%$ of the theoretical concentrations to allow us the use of the method for dissolution profiling tests. The dissolution test requirement of pharmacopoeia with reference to the acceptance criteria are $80 \%$ for the three actives, which is included into the validated range.

R.S.D.s in instrumental precision were lower for HPLC, but they were good in both cases, as much for one as for two different days (Table 3). In spite of

Table 3

Instrumental precision of the HPLC and CE methods

\begin{tabular}{|c|c|c|c|}
\hline Instrumental precision & & HPLC & $\mathrm{CE}$ \\
\hline \multicolumn{4}{|l|}{ Acetaminophen } \\
\hline Intra-assay $(n=6)$ & $\begin{array}{l}\text { Mean }(\mathrm{mg} / \mathrm{ml}) \pm \text { C.L } \\
\text { R.S.D. }(\%)\end{array}$ & $\begin{array}{l}0.5568 \pm 0.0001 \\
0.022\end{array}$ & $\begin{array}{l}0.557 \pm 0.002 \\
0.303\end{array}$ \\
\hline Intermediate $(n=12)$ & $\begin{array}{l}\text { Mean }(\mathrm{mg} / \mathrm{ml}) \pm \text { C.L } \\
\text { R.S.D. }(\%)\end{array}$ & $\begin{array}{l}0.5574 \pm 0.0006 \\
0.181\end{array}$ & $\begin{array}{l}0.557 \pm 0.001 \\
0.321\end{array}$ \\
\hline \multicolumn{4}{|l|}{ Phenylephrine } \\
\hline Intra-assay $(n=6)$ & $\begin{array}{l}\text { Mean }(\mathrm{mg} / \mathrm{ml}) \pm \text { C.L } \\
\text { R.S.D. }(\%)\end{array}$ & $\begin{array}{l}0.01110 \pm 0.00004 \\
0.341\end{array}$ & $\begin{array}{l}0.01110 \pm 0.00006 \\
0.548\end{array}$ \\
\hline Intermediate $(n=12)$ & $\begin{array}{l}\text { Mean }(\mathrm{mg} / \mathrm{ml}) \pm \text { C.L } \\
\text { R.S.D. }(\%)\end{array}$ & $\begin{array}{l}0.01110 \pm 0.00002 \\
0.343\end{array}$ & $\begin{array}{l}0.01110 \pm 0.00004 \\
0.605\end{array}$ \\
\hline \multicolumn{4}{|l|}{ Chlorpheniramine } \\
\hline Intra-assay $(n=6)$ & $\begin{array}{l}\text { Mean }(\mathrm{mg} / \mathrm{ml}) \pm \text { C.L } \\
\text { R.S.D. }(\%)\end{array}$ & $\begin{array}{l}0.00446 \pm 0.00003 \\
0.705\end{array}$ & $\begin{array}{l}0.00446 \pm 0.00005 \\
1.114\end{array}$ \\
\hline Intermediate $(n=12)$ & $\begin{array}{l}\text { Mean }(\mathrm{mg} / \mathrm{ml}) \pm \text { C.L } \\
\text { R.S.D. }(\%)\end{array}$ & $\begin{array}{l}0.00446 \pm 0.00002 \\
0.714\end{array}$ & $\begin{array}{l}0.00446 \pm 0.00003 \\
1.083\end{array}$ \\
\hline
\end{tabular}


Table 4

Method precision of the HPLC and CE methods

\begin{tabular}{|c|c|c|c|}
\hline Method precision & & HPLC & $\mathrm{CE}$ \\
\hline \multicolumn{4}{|l|}{ Acetaminophen } \\
\hline Intra-assay $(n=6)$ & $\begin{array}{l}\text { Mean }(\mathrm{mg} / \mathrm{cap}) \pm \text { C.L } \\
\text { R.S.D. }(\%)\end{array}$ & $\begin{array}{c}506 \pm 4 \\
0.792\end{array}$ & $\begin{array}{c}501 \pm 5 \\
0.935\end{array}$ \\
\hline Intermediate $(n=12)$ & $\begin{array}{l}\text { Mean }(\mathrm{mg} / \mathrm{cap}) \pm \text { C.L } \\
\text { R.S.D. }(\%)\end{array}$ & $\begin{array}{c}504 \pm 4 \\
1.237\end{array}$ & $\begin{array}{c}500 \pm 3 \\
0.930\end{array}$ \\
\hline \multicolumn{4}{|l|}{ Phenylephrine } \\
\hline Intra-assay $(n=6)$ & $\begin{array}{l}\text { Mean }(\mathrm{mg} / \mathrm{cap}) \pm \text { C.L } \\
\text { R.S.D. }(\%)\end{array}$ & $\begin{array}{l}10.2 \pm 0.4 \\
3.487\end{array}$ & $\begin{array}{l}9.8 \pm 0.4 \\
4.315\end{array}$ \\
\hline Intermediate $(n=12)$ & $\begin{array}{l}\text { Mean }(\mathrm{mg} / \mathrm{cap}) \pm \text { C.L } \\
\text { R.S.D. }(\%)\end{array}$ & $\begin{array}{l}10.2 \pm 0.2 \\
3.686\end{array}$ & $\begin{array}{l}10.1 \pm 0.3 \\
5.192\end{array}$ \\
\hline \multicolumn{4}{|l|}{ Chlorpheniramine } \\
\hline Intra-assay $(n=6)$ & $\begin{array}{l}\text { Mean }(\mathrm{mg} / \mathrm{cap}) \pm \text { C.L } \\
\text { R.S.D. }(\%)\end{array}$ & $\begin{array}{c}4.0 \pm 0.1 \\
2.965\end{array}$ & $\begin{array}{l}3.5 \pm 0.1 \\
3.495\end{array}$ \\
\hline Intermediate $(n=12)$ & $\begin{array}{l}\text { Mean }(\mathrm{mg} / \mathrm{cap}) \pm \text { C.L } \\
\text { R.S.D. }(\%)\end{array}$ & $\begin{array}{c}4.0 \pm 0.1 \\
4.126\end{array}$ & $\begin{array}{l}3.5 \pm 0.1 \\
5.497\end{array}$ \\
\hline
\end{tabular}

the improvement obtained with the injection of BGE after the sample, method precision was the weakest point for CE when comparing both techniques, but still precision can be considered acceptable for the purpose (Table 4).

\section{Conclusions}

Although in the present work the chromatographic method was only optimised from a previous one, which was developed for the main components and impurities assay, in general terms, method development is easier in CE than in HPLC, because different buffers can be tested automatically. Validation parameters for this particular situation were adequate for both methods, although linearity has resulted slightly better and precision slightly poorer for CE. Analysis time is shorter with the CE method and solvent consumption was considerably lower, which is a great economical benefit. Nevertheless, buffer preparation was a bit more difficult due to the presence of the surfactant. Finally, the main drawback to establish the CE method as routine in the pharmaceutical laboratory was that trained staff is more common to work with HPLC than with CE.

\section{References}

[1] U.V. Banakar, M.C. Makoid, Drug Dissolution and Bioavailability (seminar handouts), Technomic Publishing AG, Basel, Switzerland, 1994.
[2] B. Hoener, L.Z. Benet, in: G.S. Banker, C.T. Rhodes (Eds.), Modern Pharmaceutics, Marcel Dekker, New York, 1990.

[3] The United States Pharmacopeia 27, NF 22, Revision, United States Pharmacopeial Convention Inc., Rockville, USA, 2004.

[4] European Pharmacopoeia, vol. 4.8, fourth ed., 2004.

[5] A. Marín, E. García, A. García, C. Barbas, J. Pharm. Biomed. Anal. 29 (2002) 701-714.

[6] H. Senyuva, T. Ozden, J. Chromatogr. Sci. 40 (2002) 97100.

[7] G.V. Kanumula, B. Raman, I.C. Bhoir, Indian Drugs 38 (2001) 203-207.

[8] D.J. Krieger, J. Assoc. Off. Anal. Chem. 67 (1984) 339341.

[9] V. Das Gupta, A.R. Heble, J. Pharm. Sci. 73 (1984) 15531556.

[10] X. Zhao, B. Tan, H. Zhang, Huaxi Yaoxue Zazhi 13 (1998) 271-273.

[11] G. Indrayanto, A. Sunarto, Y. Adriani, J. Pharm. Biomed. Anal. 13 (1995) 1555-1559.

[12] A. García, F.J. Rupérez, A. Marín, A. de la Maza, C. Barbas, J. Chromatogr. B 785 (2003) 237-243.

[13] K.D. Altria, A.B. Chen, L. Cloths, LC GC Europe (CE Currents) 2-7 December 2001.

[14] Y.J. Heo, K.-J. Lee, Yakhak Hoechi 41 (1997) 539-546.

[15] S. Ji, Y. Chai, Y. Wu, D. Liang, Z. Xu, X. Li, Yaowu Fenxi Zazhi 18 (1998) 170-173.

[16] D. Zou, X. Wu, G. Nan, Yaowu Fenxi Zazhi 17 (1997) 160163.

[17] B.Y. Sun, A.J. Huang, Y.L. Sun, Z.P. Sun, Chin. Chem. Lett. 8 (1997) 619-622.

[18] L. Suntornsuk, Electrophoresis 22 (2001) 139-143.

[19] H. Nishi, T. Fukuyama, M. Matsuo, S. Terabe, J. Chromatogr. 498 (1990) 313-323.

[20] K.D. Altria, H. Fabre, Chromatographia 40 (1995) 313-320. 